\title{
69. GEOLOGIC AND TECTONIC HISTORY OF THE GULF OF CALIFORNIA ${ }^{1}$
}

\author{
D. G. Moore and J. R. Curray, Scripps Institution of Oceanography, La Jolla, California
}

\begin{abstract}
Deep sea drilling and associated geophysical surveys have provided samples and data that offer new insight into the nature and timing of the evolution of the Gulf of California. We propose a scenario for the opening of the Gulf that begins about 5.5 Ma, when the Pacific-Farallon (Guadalupe) spreading center propagated northeastward, and rightslip transform motion between the Pacific and North American plates jumped from offshore to the eastern side of the Peninsular Range batholith to initiate motion on the present San Andreas Fault and opening of the Gulf. Assuming constant $5.6 \mathrm{~cm} / \mathrm{yr}$ displacement between the Pacific and North American plates since that time, the Baja California crustal block and Southern California Terrace of the Pacific Plate have moved $300 \mathrm{~km}$ to the northwest relative to North America. This is the maximum closure that can be attained in paleogeographic reconstruction of the region by retrofitting along the azimuth of the major Gulf fracture zones. About $300 \mathrm{~km}$ is also the amount of offset required by Gastil and his colleagues for matching geological phenomena across the Gulf and is the amount required by Matthews, Ehlig, and others for restoring offsets along the San Andreas Fault in Central and Southern California. We do not propose that any of this $300 \mathrm{~km}$ of opening resulted from formation of an earlier proto-Gulf, but instead postulate opening by a single, two-phased process. The first phase of diffuse extension included rifting and dilation of continental crust, accompanied by dike injection and rapid subsidence at the tip of the Peninsula and at the conjugate Tres Marias Block, where the foundered Maria Magdalena Rise now lies. This first phase also included formation of ocean crust without lineated magnetic anomalies. A gradual change to the second phase of opening with formation of lineated magnetic anomalies at the mouth of the Gulf was completed about 3.2 Ma. At about this same time, extension by continental attenuation within the Gulf had nearly ended, and generation of new crust began at both diffuse and discrete spreading centers through the injection of basalt into soft sediments. This model implies that the Peninsula separated essentially as a unit from the mainland; it does not require a spreading axis jump at the Gulf mouth $3.5 \mathrm{Ma}$, and it specifically rejects northwestward subduction beneath the tip of the Peninsula. Our scenario also predicts that no marine basin sediments older than latest Miocene ( $5.5 \mathrm{~m} . \mathrm{y}$.) will be found associated with the Gulf. It also requires that virtually all of the interplate motion of the past 5.5 m.y. has been taken up within the Gulf and on the modern San Andreas Fault and its direct branches. Seismicity on other faults in the region is either related to flexing of near-plate edge areas as a result of curved plate edge surfaces, or it results from tectonic activity too young to have been recorded in the long-term geological record of offset terranes.
\end{abstract}

\section{INTRODUCTION}

Deep sea drilling at the young passive margin on the southeastern tip of Baja California (Sites 474, 475, and 476) has made it possible to define the ocean/continental crust boundary and, together with associated geophysical studies, has clarified the subsidence and seafloor spreading history of this youthful margin (Curray et al., this volume, Pt. 2). A most significant finding is that the continental crust outermost on the margin had already foundered to oceanic depths before initiation of the first recognizable lineated magnetic anomaly of the adjacent ocean crust. From sea-floor magnetic anomalies, it appears that the oldest ocean crust along the drilling transect is $3.2 \mathrm{Ma}$ (Larson et al., 1968; Lewis et al., 1975; Ness et al., 1981; Curray et al., this volume, Pt. 2), a figure compatible with biostratigraphic dating of oldest sediment recovered from over that crust at Site 474. Oldest deep-water sediment on the nearby continental crust at Sites 475 and $\mathbf{4 7 6}$, however, is dated at about $4.5 \mathrm{Ma}$. This age difference clearly implies that the continental margin subsidence must be related to rifting that predated, by a million years, sea-floor spreading as recorded by magnetic anomalies. This demonstra-

\footnotetext{
${ }^{1}$ Curray, J. R., and Moore, D. G., Init. Repts. DSDP, 64: Washington (U.S. Govt. Printing Office).
}

tion of a period of subsidence prior to the advent of the usual evidence for sea-floor spreading had previously been interpreted as strong support for arguing the existence of a "proto-Gulf of California" initiated by an earlier period of opening, possibly related to a different tectonic regime. We now suggest that the foundering of the early continental margin at the Gulf mouth and adjacent to major rifting centers within the southern Gulf was not necessarily related to a different, earlier tectonic regime. Instead, we propose that it was simply the first expression of a single, continuing, multiphased process that began about 5.5 Ma, when plate-edge transform motion jumped from the sea floor west of Southern and Baja California to the east side of the present Peninsula Range Batholith to initiate opening of the Gulf of California and movement on the San Andreas Fault. This model is further supported by demonstration that the age of the oldest oceanic crust is diachronous around the tip of Baja California: as old as about $4.7 \mathrm{~m} . \mathrm{y}$. west of the drilling transect and possibly $4.5 \mathrm{~m} . \mathrm{y}$. north of the transect (Curray et al., this volume, Pt. 2).

To support this proposal we will present evidence arguing against (1) earlier origins of the Gulf of California and the San Andreas Fault, (2) movements within the Gulf and along the San Andreas greater than or less than about $300 \mathrm{~km}$; (3) the existence of sedimentary rocks unequivocally deposited in a nascent Gulf of California older than latest Miocene (5.5 Ma). 
Drilling in the Guaymas Basin (Sites 477, 478, and 481) has also provided information giving important insight into the processes of crustal accretion during the early stages of forming a new ocean basin (Pt. VIII of this volume, Pt. 2). It verifies the concept that new sea floor may grow without magnetic anomaly patterns forming. This early accretion occurs through injection of dikes and sills into rapidly deposited, soft, saturated sediments above spreading centers (Einsele, this volume, Pt. 2).

Significant previous studies of the Gulf and ideas on its origin and geological history are reviewed in another chapter by Moore and Curray "Objectives of Drilling on Young Passive Continental Margins"' (this volume, Pt. 1). In this chapter we (1) review the geological history of the region prior to the beginning of rifting and formation of the new ocean basin, (2) review the plate tectonic history leading up to this initiation of rifting, (3) discuss geological and geophysical constraints on models for the origin and evolution of the Gulf, and (4) present a new scenario for the opening of the Gulf through a single, continuous process that began in latest Miocene time and has continued to the present. The timing and mechanism of our proposed model for the opening of the Gulf have significant implications for the tectonic history and future seismicity of Southern and central California. We discuss these implications in a concluding section.

\section{PLATE TECTONIC AND GEOLOGIC HISTORY OF THE REGION PRIOR TO THE OPENING OF THE GULF}

In late Oligocene time, the spreading ridge system separating the Pacific and Farallon plates encountered the North American Plate, and two triple junctions formed (Atwater, 1970; Atwater and Molnar, 1973). The northern, or Mendocino, transform-transform-trench triple junction migrated to the north and the southern, or Rivera, ridge-trench-transform triple junction migrated south as the two plates converged in an eastwest direction. As the triple junctions moved away from one another, a right-lateral transform fault formed the boundary between the Pacific and North American plates. Thus the $100 \mathrm{~m} . \mathrm{y}$. history of subduction along the west coast came to an end with the passing of the triple junctions.

The effects of this transform faulting and the passing of the triple junctions caused a major tectonic reorganization in western California and initiated a series of Neogene basins. A major phase of this basin formation is believed to have occurred with a change from more northerly to more westerly relative shear motion between the Pacific and North American plates over the period between 21.5 and $4.5 \mathrm{Ma}$ (Blake et al., 1978). More specifically, the change in relative shear direction is suggested (Dickinson and Snyder, 1979) to have resulted in the instability (McKenzie and Morgan, 1967) of the Rivera triple junction for much of its southerly passage down the coast. The resulting extensional deformation was believed responsible for the initial formation of the fault-bounded California Continental Borderland Basins off Southern California and northern Baja California.
Study of the origin of Continental Borderland structure and geology was carried a step further by Crouch (1979), who proposed that a major ridge jump occurred off central Baja California about $18 \mathrm{Ma}$ as a result of the instability of the triple junction. This jump initiated rifting, which formed the deeper, volcanic-rock-floored southern borderland-an event suggested earlier by Suppe (1970). Crouch suggested that the rifting and attendant activation of a northwest-trending transform fault further inshore were the mechanism for juxtaposing paired "Great Valley" and "Franciscan" type belts of terranes in the Southern California Continental Borderland.

Although the steady southeastward migration of the unstable Rivera triple junction can explain the California Continental Borderland structure, the absence of a comparable terrane to the south requires a different history. It has been suggested (Dickinson and Snyder, 1979) that this difference may be related to a period of very rapid migration of the triple junction down the southern Baja California coast as a segment of the rise crest pivoted into the subduction zone, in the manner suggested by Menard (1978). More recently, bathymetric and magnetic-anomaly studies have led to the conclusion (Klitgord and Mammerickx, in press; Mammerickx and Klitgord, in press) that, by about $15 \mathrm{Ma}$, the spreading center south of the Continental Borderland off Baja California and down to $23^{\circ} 30 \mathrm{~N}$ had slowly rotated counterclockwise, until it was nearly parallel to the adjacent subduction zone to the east. Thus, it is speculated that this entire section of the spreading ridge reached the subduction zone at essentially the same time, $12.5 \mathrm{Ma}$ (Mammerickx and Klitgord, in press), although several small offsets in this section of spreading ridge have probably remained as abandoned segments (Menard, 1978; Batiza and Chase, in press; Ness et al., 1981). This, in effect, resulted in an abrupt jump down the coast of the triple junction at that time and precluded extensional basin formation like that of the Continental Borderland to the north. This model implies that nearly the entire length of the resulting transform fault off southern Baja California was activated about $12.5 \mathrm{Ma}$ and that it continued active until the jump to the east side of the Peninsular Range Batholith and activation of the San Andreas Fault about 5.5 Ma (an event discussed in more detail in a later section). The postulated transform faulting off southern Baja California that Spencer and Normark (1980) mapped-the Tosco-Abreojos Faultprobably acted as a plate boundary for $7 \mathrm{~m}$.y. Despite this long period of offshore strike-slip motion, however, that part of the Baja California Pacific continental margin has retained its primary structural identity as a subduction margin (Huehn, 1977; Coperude, 1978).

At the time of the earliest Pacific/North American transform boundary in Southern California (late Oligocene and early Miocene), there was volcanic activity in areas now east of the Gulf of California (Gastil et al., 1979). Streams draining the northern part of this area flowed southwest across the region now occupied by the Peninsular Ranges (Minch, 1972) and there was neither a Gulf of California nor a Peninsular Mountain Range. Farther south, streams draining the volcanic terrane 
flowed west at least as far as the present peninsula of Baja California (Gastil et al., 1979). Volcanic activity then shifted westward abruptly about $20 \mathrm{Ma}$ and the shift was accompanied by a change in the nature of the rocks generated. Predominantly rhyolitic rocks gave way to andesitic rocks that were extruded until $17 \mathrm{Ma}$ in a belt centered close to the eastern edge of present Baja California and the western edge of Sonora and Nayarit (Gastil et al., 1979). Gastil et al. (1981) suggest the probability that this volcanic belt is underlain by a band of granitic rocks analogous to those beneath the Cascades. Dickinson and Snyder (1979) have inferred that arc magmatism was terminated over the entire region of the Sierra Madre Occidental east of the present Gulf of California about 20 Ma because of the passage of a critical isochron within the subducted slab. Volcanic activity was not terminated, however, but was shifted oceanward. As Gastil et al. (1979) have noted, the 17-22 m.y. old volcanic belt located on both sides of the present Gulf continued, and the western part of Baja California has erupted alkaline basalt and basalt-related andesite from middle Miocene to nearly historic time. It is apparent that although arc magmatism may be extinguished by the passage of a critical isochron of the subducted slab, arc volcanism is not extinguished, but is made to shift seaward and become more complex as hotter and thinner young oceanic lithosphere is subducted.

\section{CONSTRAINING FACTORS IN A HYPOTHESIS FOR TECTONIC EVOLUTION OF THE GULF OF CALIFORNIA}

\section{Introduction}

Since Tuzo Wilson (1965) first suggested that the San Andreas Fault and the Gulf of California were a common manifestation of a plate-edge transform fault, the timing and magnitude of movement on the San Andreas Fault has been critical to understanding the tectonic history of the Gulf. Strong new evidence on this movement, coupled with data that limit movement on faulting across the Gulf, now invalidate any hypothesis that does not take these facts into account. Similarly constraining are the fit of paleogeographic reconstructions based on maximum allowable movement, the timing of the initial opening of the Gulf in the context of the known relative motion of the Pacific and North American plates, the paleomagnetic record of plate motions, and the pattern of mapped fracture zones and extensional faulting within the Gulf. Finally, the age of sedimentary rocks recovered from dredging the oldest exposed sections along fracture zones of the deep Gulf (Moore, 1973) place limitations on the age of inception.

\section{Timing and Amount of Displacement on the San Andreas Fault and across the Gulf of California}

The amount of displacement along the San Andreas Fault has been the subject of serious debate for many years. Unfortunately, since the introduction of the plate tectonics model for Cenozoic evolution of the western United States (Atwater, 1970) this debate has been clouded by the way in which the terms San Andreas
Fault, San Andreas Fault System, and proto-San Andreas Fault have been used. These terms all identify the earliest transform motion between the Pacific and North American plates following the late Oligocene encounter of the Pacific/Farallon spreading center and the Farallon/North American subduction zone. Proto-San Andreas Fault has also referred to Late CretaceousPaleogene transform faults between the North American and the Kula plates, necessary to explain $600 \mathrm{~km}$ of offset. The Pacific/Farallon transform motion has, indeed, been active since late Oligocene time, but not always on the San Andreas Fault per se. We propose to demonstrate that the San Andreas Fault per se and its branches have been active only for about the past 5.5 m.y. and came into being with the first opening of the Gulf of California.

There is now strong evidence favoring a total rightslip of about $300 \mathrm{~km}$ along the San Andreas and its branches in both central and Southern California. Ehlig (1981) has documented this evidence. He cites one of the most precise indicators of total offset in central California to be the correlation of the $23.5 \mathrm{~m}$.y. old Pinnacles and Neenach volcanic formations (Matthews, 1976). This important correlation places the Salinian basement, upon which the Pinnacles volcanics rest, against the southwestern edge of the Mojave Desert before faulting began in the late Miocene. It demonstrates $315 \mathrm{~km}$ of right slip and also shows that the San Andreas Fault has always been essentially on the position of its present trace in this sector. It further requires that the Transverse Range Province be a product of late Cenozoic deformation (Ehlig, 1981). In Southern California, a correlation of distinctive clasts in a fluvial conglomerate of the upper Miocene Mint Canyon Formation with a porphyry that forms dikes at the north end of the Chocolate Mountains on the opposite side of the San Andreas Fault requires a total right slip of $240 \mathrm{~km}$, no older than late Miocene. Another $60 \mathrm{~km}$ of right slip occurred along the San Gabriel Fault when it was located near the northeast margin of the present Salton Trough and formed the main trace of the San Andreas. The modern trace of the San Andreas developed to the east of the San Gabriel Fault during the Pliocene and subsequently offset the San Gabriel to its present position (Ehlig, 1981). Thus, the total right slip on the Southern California sector of the San Andreas is also about $300 \mathrm{~km}$.

The geology flanking the Gulf of California has not been studied in so much detail as that of central and Southern California, but Gastil and his colleagues (Gastil and Krummenacker, 1977; Gastil et al., 1981) have shown that at least one tie point across the northern Gulf of California effectively defines the post-middle Miocene right-slip motion along the prominent fracture zones west of Guaymas. In Baja California, a southwest-trending channel in Mesozoic granite, southwest of San Felipe, holds conglomerate containing unmetamorphosed clasts of limestone and quartzite with early Permian fossils. In Sonora, northeast of Bahía Kino, this distinctive conglomerate is found on each side of Valle Noriga. The total right-slip offset, parallel to the 
transforms of the northern Gulf, of these two conglomerate localities is about $300 \mathrm{~km}$. Two elements of Mesozoic structure also support a right-slip transform offset of no more than about $300 \mathrm{~km}$ (Gastil et al., 1981). These are the distributions of a 110 to $140 \mathrm{~m} . \mathrm{y}$. old gabbro and Aptian-Cenomanian marine andesite. There is, in the geological record, therefore, a remarkable concurrence of evidence from central California, Southern California, and across the northern Gulf of California that no more than $300 \mathrm{~km}$ of right-slip motion has taken place on the San Andreas Fault per se and its direct branches and the contiguous, en echelon transforms of the Gulf of California north of Guaymas. Furthermore, the evidence shows that this motion has been restricted to after the mid-Miocene or later and that it does not increase when offset units of greater age are compared.

\section{Fit of Paleogeographic Reconstruction}

The remarkable concurrence of geologic evidence favoring about $300 \mathrm{~km}$ of right slip on the San Andreas Fault and across the northern Gulf of California implies that a monolithic opening of the Gulf should also allow a restoration of this $300 \mathrm{~km}$ of right-slip motion along the approximate azimuth of the Tamayo Fracture Zone at the Gulf mouth. Figure 1 is constructed by restoring $300 \mathrm{~km}$ of motion along the average azimuth of the most prominent Gulf fracture zones $\left(124^{\circ} \mathrm{T}\right)$. The reconstruction entirely closes the northern Gulf and essentially closes the 1000-meter isobath at the tip of the Peninsula with that at the north side of Islas Tres Marias. Overlap of the 2000-meter isobath occurs. The continent/ocean boundary is at $3000 \mathrm{~m}$ in most places, going locally to $2000 \mathrm{~m}$. A prominent escarpment marks the edge of continental crust at the base of the continental slope off Baja California. This boundary clearly fits like a piece of picture puzzle against the curve of the base of the Tres Marias Escarpment. We conclude that the restoration of $300 \mathrm{~km}$ of motion along the Gulf fracture zones is near the maximum that can be attained without serious overlap of continental segments resulting. The good fit of this restoration, furthermore, supports the concept of separation of the Peninsula essentially as a unit from the mainland of Mexico.

\section{Magnetic Anomalies, Bathymetry, and Age of the Ocean Crust at the Mouth of the Gulf of California}

Although the bathymetry and magnetic anomaly patterns at the mouth of the Gulf of California were utilized to propose, first, a sea-floor spreading and transform-fault origin of the Gulf, it was recognized from earliest studies that the region on the southeastern flank of the spreading ridge at the mouth of the Gulf was of complex origin. Moore and Buffington (1968) proposed an age of $4 \mathrm{Ma}$ for the beginning of the present spreading regime, based on an axial spreading rate and the distance to the base of the slope off the tip of the Baja Peninsula. They also noted that on the eastern flank of the ridge southwest of Islas Tres Marias (Fig. 2), there abruptly occurred an anomalously thick sequence of pelagic sediment that suggested an older age for that terrane. Larson et al. (1968) and Larson (1972) document-

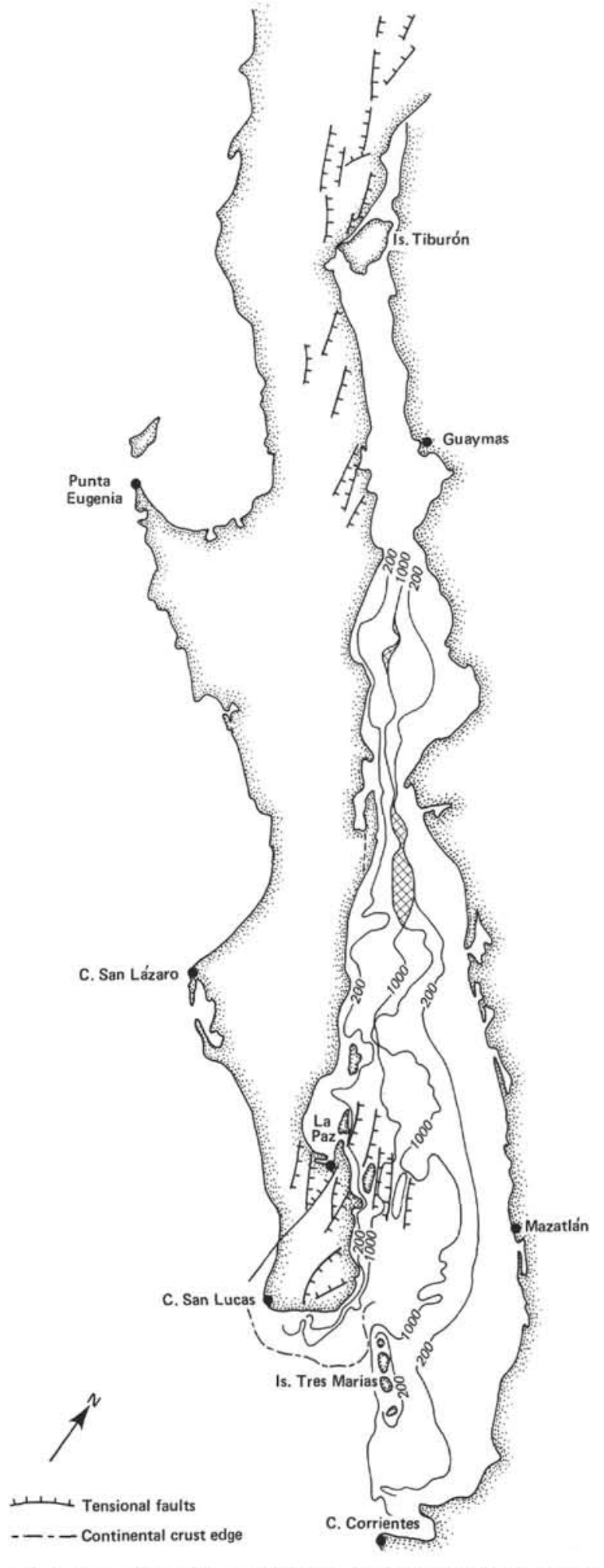

Figure 1. Reconstruction showing the Gulf of California closed by translating the Baja California Peninsula $300 \mathrm{~km}$ back along the azimuth of the major fracture zones $\left(124^{\circ}\right)$. The northern Gulf is entirely closed and the remainder is largely closed at least to the 1000 -meter isobath (hachured areas are overlap of 1000 -m contours). The 1000-meter isobath at the southeast tip of the Peninsula nearly abuts that north of the Tres Marias block. The dashed line south and southeast of the tip of the Peninsula marks the prominent scarp at the continental crust edge. Note that this boundary fits neatly around the northwest tip of the Tres Marias continental block. Onshore faults are from USGS map I-512 (1966). 


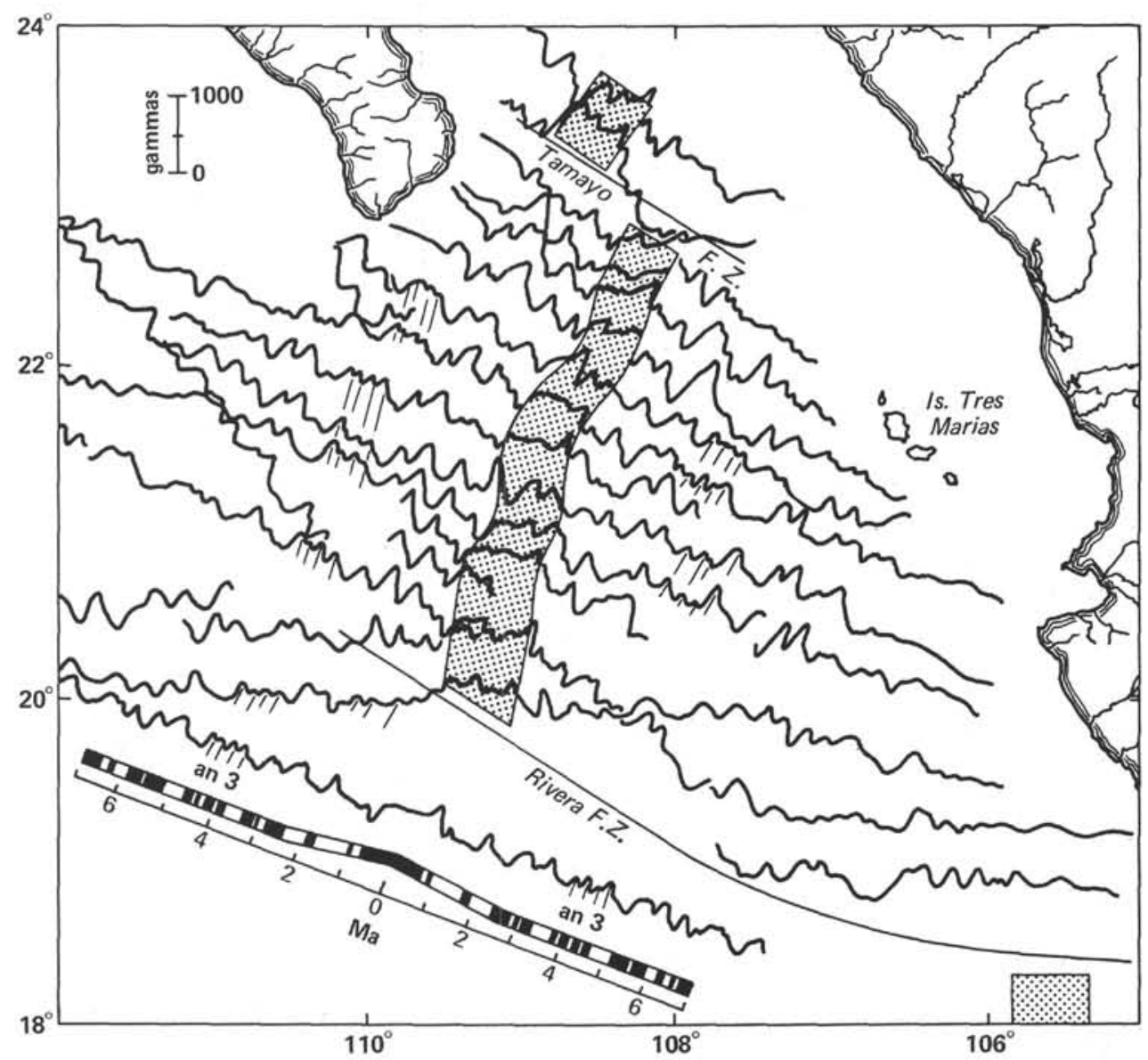

Figure 2. Magnetic anomalies at the mouth of the Gulf of California, adapted from Larson et al. (1968). Note that the anomalies immediately to the southeast of Islas Tres Marias are atypical of oceanic anomalies. Shaded areas show central anomaly. (an $3=$ Anomaly 3 .)

ed the magnetic anomaly pattern for that same area and concluded that the eastern flank was not nearly so clear as that of the west and that the region just west of Islas Tres Marias and south to about $21^{\circ} 30 \mathrm{~N}$ was especially characterized by incoherent anomalies. South and west of this region the correlations are better where Larson (1972) and Chase et al. (1970) document a continuous chronological sequence of anomalies from $10 \mathrm{Ma}$ to the present. Although Larson (1970) considered the possibility that the area of thick sediment just southeast of Islas Tres Marias might be 4 to $6 \mathrm{~m}$.y. old (or even older), he did not accept this idea, because it would require that the spreading center generating the crust had jumped westward about $4 \mathrm{Ma}$ to the exact foot of the Baja California slope, generating new anomalies there. Mammerickx (1980) has recently utilized new bathymetric data interpretations and existing magnetics to reexamine the history of spreading at the Gulf mouth. This study recognizes three newly designated fracture zones, W, X, and Y, that trend more northerly than the active Gulf fracture zones and that parallel the trend of and lie south of the Tres Marias scarp, which is also designated as an earlier fracture zone. Fracture Zones W, $\mathrm{X}$, and $\mathrm{Y}$ do not offset the modern trend of the East Pacific Rise in the Gulf mouth. Mammerickx proposes that, $6 \mathrm{Ma}$, spreading was initiated north of Fracture
Zone W (the approximate northeasterly limit of the correlatable anomalies of Larson, 1970) along a new segment of ridge extending to the "Tres Marias Fracture Zone." This segment continued to generate crust until 3.5 Ma. At that time, there took place a major reorganization that caused the segment of the spreading ridge between Fracture Zones W and Tres Marias to jump 100 $\mathrm{km}$ westward (precisely to the base of the Baja slope), to become aligned with the spreading system to the south and to initiate opening of the modern Gulf of California. At the same time, the "Tres Marias Fracture Zone" and Fracture Zones $\mathrm{W}, \mathrm{X}$, and $\mathrm{Y}$ were abandoned.

Ness and his colleagues at Oregon State University (Ness et al., 1981; Ness and Lyle, in press) have, since 1975 , collected a new set of magnetic, bathymetric, and gravity data from the vicinity of the mouth of the Gulf and have also utilized data from Leg 63 (Yeats, Haq, et al., 1981) to prepare a crustal isochron map of the area. Their interpretation of magnetic anomalies, particularly in the anomalous area to the southeast of Islas Tres Marias on the east flank of the spreading ridge at the Gulf mouth and in the area north of the Tamayo Fracture Zone, leads them to propose a radically different history of the opening of the Gulf from that of earlier hypotheses. Ness et al. (1981) interpret the anomalies southwest of the Tres Marias and north of $21^{\circ} \mathrm{N}$ as ex- 
tending progressively back to at least $5.3 \mathrm{Ma}$. This is in contrast with earlier interpretations (Larson, 1972) of these anomalies as incoherent. Ness et al. also believe that oceanic crust was exposed at the mouth of the Gulf by at least $9 \mathrm{Ma}$, on the evidence of magnetic anomaly correlations in the Gulf mouth south of the Tamayo Fracture Zone. Because the age of oceanic crust southeast of the tip of Baja is only 3.5 m.y., they conclude the spreading ridge at the Gulf mouth is uncentered. This, they believe, implies an episode of at least 5 m.y. of subduction beneath the southeast tip of Baja. North of the Tamayo Fracture Zone, Ness and Lyle (in press) interpret the pattern of anomalies as requiring a modern 70 $\mathrm{km} / \mathrm{m} . \mathrm{y} .(7 \mathrm{~cm} / \mathrm{yr})$ separation of the Pacific and North American plates-a rate $25 \%$ greater than the $56 \mathrm{~km} /$ m.y. $(5.6 \mathrm{~cm} / \mathrm{yr})$ rate of generation further south. This they accommodate on a Trans-Mexican Plate, south of the Trans-Mexican volcanic belt, that moves right laterally to North America at a rate greater than $14 \mathrm{~km} / \mathrm{m}$.y. $(1.4 \mathrm{~cm} / \mathrm{yr})$. Basing their argument primarily on the Yeats and Haq (1981) reconstruction of the position of the Magdalena Fan, Ness and Lyle (in press) propose that the Gulf began opening about $14 \mathrm{Ma}$ and that by 13 $\mathrm{Ma}$ basins had begun to form.

From the foregoing brief discussions of data interpretations and hypotheses of evolution of the region of the Gulf mouth, we now hope to extract a set of conclusions which are compatible with our previously discussed constraints on hypotheses for the origin of the Gulf. There are several aspects of the Ness et al. (1981) and Ness and Lyle (in press) hypothesis that are untenable in the context of our accepted constraints.

First, interpretation of anomalies north of the Tamayo Fracture Zone that requires $70 \mathrm{~km} / \mathrm{m}$.y. motion on the Pacific/North American plate boundary is unacceptable, for the following reasons: (1) if the $14 \mathrm{~m} . \mathrm{y}$. time for first opening is accepted, $630 \mathrm{~km}$ of motion along the San Andreas Fault are required, rather than the 300 that are mapped (Ehlig, 1981). (2) Modern motion on a Trans-Mexican Transform Fault of $1.4 \mathrm{~cm} / \mathrm{yr}$ is required. Such an active fault is unknown, and according to Gastil and Krummenacker (1981) there can have been no such motion for the past 10 m.y. (3) The hypothesis also violates the maximum $300 \mathrm{~km}$ movement across the northern Gulf (Gastil and Krummenacker, 1981). Finally, (4) it exceeds the maximum of 300 km possible closure implied by our Figure 1.

Second, the Ness et al. (1981) interpretation that anomalies on the east flank of the Gulf mouth spreading ridge are continuous out to at least $5.3 \mathrm{~m} . \mathrm{y}$. north of $21^{\circ} 15 \mathrm{~N}$ and the corollary to that interpretation requiring up to $5 \mathrm{~m}$.y. of underthrusting of the tip of Baja are unacceptable, because of the following: (1) Seismic reflection data, including multichannel CDP data across the young margin at the tip of Baja (Curray et al., this volume, Pt. 2), clearly show structure typical of a youthful collapsed margin and cannot be interpreted to suggest underthrusting. (2) A large amount of analog and CDP seismic data around the tip of Baja California clearly shows that no topographic or filled trench wraps around the south end of the Peninsula.
Third, the 14 Ma time of first opening of the Gulf utilized by Ness and Lyle (in press) is based on the Yeats and Haq (1981) Magdalena Fan reconstruction, the validity of which in both time and space we later question, although we support the concept that the Magdalena Fan has been displaced. For the present, then, we reject the $14 \mathrm{~m} . \mathrm{y}$. time as invalid because it both utilizes the Yeats and Haq reconstruction and violates the plate tectonics scenario of Mammerickx and Klitgord (in press).

In summary, we conclude that the hypothesis of Ness and his colleagues is an ad hoc fitting of a hypothesis to an interpretation through two very tenuous correlations of magnetic data: one north of the Tamayo Fracture Zone and the other consisting of the anomalies east of the spreading ridge and just southwest of the Tres Marias. The hypothesis, furthermore, disregards available or published seismic data on the structure of the southern peninsula margin.

In addition to concluding that underthrusting of the tip of Baja is unacceptable, we also conclude that the magnetic anomalies just southwest of the Tres Marias are incoherent and uncorrelatable, as described by Larson (1972). Uncorrelatable anomalies here are also a strong argument against this terrane being an old, now abandoned, spreading ridge as postulated by Mammerickx (1980).

\section{Other Factors}

Three other factors important in formulating a history for the evolution of the Gulf are (1) the age of oldest sediment deposited in the Gulf; (2) the structure of the continental margin flanking the newly formed ocean basin and that of adjacent terranes; and (3) the significance of well-defined major fracture zones of the Gulf within the context of the opening history which we present here.

\section{FORMATION AND EVOLUTION OF THE GULF OF CALIFORNIA DURING THE PAST 5.5 MILLION YEARS}

\section{Assumptions}

In preparing this hypothesis we accept a present-day relative motion between the North American and Pacific plates of $5.6 \mathrm{~cm} / \mathrm{yr}$, as determined from a worldwide data set (Minster and Jordan, 1978), and we assume that that motion has been constant over the period when the Gulf of California was forming. We believe that seafloor magnetic data at the Gulf mouth support this rate (Lewis et al., 1975; Ness et al., 1981). We accept the idea of Mammerickx and Klitgord (in press) and Klitgord and Mammerickx (in press) that at $12.5 \mathrm{Ma}$ the spreading center, which had been nearly parallel to the trench off Baja to the east, was abandoned. We concur with their belief that the spreading center off southern Baja was either consumed or that only parts of it reached the subduction zone, leaving a narrow piece of Farallon (Guadalupe) Plate along the southern Baja coast.

These assumptions place a strong restriction on models for opening the Gulf and essentially preclude the popular earlier concept of a "proto-Gulf" possibly formed 
by northwesterly movement of the Peninsula in a tectonic regime different from that now in existence. We must, therefore, now adopt a hypothesis to explain evidence formerly used to favor a "proto-Gulf" as consonant with approximately uniform motion along the entire San Andreas-Gulf transform system.

In a recent study of the Gulf of Aden, Cochran (1981) noted that the amount of motion recorded along the Levant Shear and in the Gulf of Suez implies that between 80 and $160 \mathrm{~km}$ of extension occurred in the Gulf of Aden and Red Sea before lineated magnetic anomalies and mid-ocean ridge topography began to form. He suggests that this early "diffuse extension" involves dike injection and rotational normal faulting within a broad environment of rifting in the magnetic quiet zone or zone of uncorrelatable anomalies ubiquitous in rifted margins. Cochran also pointed out that Moore (1973) had demonstrated that the motion recorded by sea-floor lineated anomalies at the mouth of the Gulf of California was insufficient to close the Gulf. Cochran (1981) concluded that there could be a region of diffuse extension in the areas landward of the seafloor magnetic anomalies similar to the area he documented for the Gulf of Aden. We accept Cochran's concept of an early phase of diffuse extension or rifting preceding generation of lineated magnetic anomalies; we propose the following scenario for the tectonic history of the Gulf and the sea floor at its mouth.

\section{Offshore Transform Faulting: 12.5 Ma to 5.5 Ma}

Prior to $12.5 \mathrm{Ma}$, the spreading center of the East $\mathrm{Pa}$ cific Rise lay west of Baja California and gradually rotated counterclockwise during late Oligocene to middle Miocene time until it was nearly parallel to the subduction zone to the east (Fig. 3). The spreading center had also migrated closer through time to the subduction zone and, in response, volcanism which until about 20 Ma was located east of the present Gulf of California had migrated westward to the vicinity of the present Gulf where it continued active until about $17 \mathrm{Ma}$. From about $17 \mathrm{Ma}$ until $12.5 \mathrm{Ma}$, hot, thin, young crust was being carried into the subduction zone and complex volcanism occurred in the western parts of the present Peninsula continuing until nearly the present time. During all of the time before $12.5 \mathrm{Ma}$, the subduction zone was active along the entire Baja California coast and contiguous to the Middle America subduction zone. In the vicinity of the present Gulf mouth, our reconstruction (Fig. 3) shows that Cabo San Lucas existed at the northern end of a broad promontory that extended south beyond the present Tres Marias. The Tres Marias scarp in its present form did not exist. The terrane of the promontory was a granitic high that probably was, in part, the source area for the rapidly deposited quartzofeldspathic sand turbidites of the Magdalena Fan of Yeats and Haq (1981), which lay to the west beyond the filled trench. Submarine canyons west of Cabo San Lucas probably acted as conduits for the turbidites.

Some $12.5 \mathrm{Ma}$, the Pacific-Farallon (Guadalupe) spreading center was abandoned along the Baja coast and the newly active spreading ridge trended more westerly toward the coast south of the present tip of Baja
(Fig. 4). At this time all subduction ceased west of southern Baja California. The Tosco-Abreojos right-lateral transform fault (Spencer and Normark, 1980) was activated, together with a short left-lateral transform fault connecting the new spreading center to a new northern extension of the subduction zone of the Middle America Trench to the southeast. This latter fault is probably equivalent to the Esplandian Fracture Zone of Ness et al. (1981). A transform-transform-ridge triple junction was thus formed and all Pacific/North American plate motion was taken up on these faults. The precise position and nature of the triple junction are not highly constrained and could have varied somewhat from this placement, which is based on fit to sea-floor anomaly patterns (see, for example, Curray et al., this volume, Pt. 2). Utilizing the configuration of Figure 4, we place the Magdalena Fan west of the newly active triple junction and southwest of the Tosco-Abreojos Fault. During the next $7 \mathrm{~m}$.y. (from 12.5-5.5 Ma) we propose that spreading continued uniformly on this part of the ancestral East Pacific Rise and that relative right-slip motion across the Tosco-Abreojos Fault was about $3.7 \mathrm{~cm} / \mathrm{yr}$, with the result that the Magdalena Fan was cut off from its source and carried, relative to the coast, about 260 $\mathrm{km}$ northwest to its modern position off Magdalena Bay, where it was drilled on Leg 63. Spencer and Normark (1980) had suggested approximately $270 \mathrm{~km}$ of offset along this fault between 10 and $4 \mathrm{Ma}$.

Leg 63 drilling showed that prior to $13 \mathrm{Ma}$, the depositional rate on the Fan was significantly greater than after that time and that quartzo-feldspathic sand turbidites were cut off at that time. Yeats and Haq (1981) proposed that the deceleration in depositional rate and the change in lithology resulted because the Fan had been cut off from its source by movement on a transform fault; they presented a hypothetical restoration of terrane in the vicinity of the Gulf mouth to account for this cut-off. Our Figure 5 is a variation of their reconstruction which, we believe, more nearly satisfies both the timing of the unconformity and change in lithology of the Magdalena Fan and the time of activation assigned the Tosco-Abreojos Fault by Mammerickx and Klitgord (in press). Our restoration, furthermore, does not require that the Cape move $175 \mathrm{~km}$ westward, relative to Islas Tres Marias, as the Yeats and Haq model does. We do not believe this large westward movement can be accommodated by extension within the Gulf because it requires transport of the southern part of the Peninsula across the bathymetric trends off the older fracture zones.

Throughout this 7 m.y. period of active offshore transform motion on the plate edge, the triple junction southeast of Cabo San Lucas may have become increasingly unstable as a result of changes in azimuth of shear between the Pacific and North America plates (Blake et al., 1978; Spencer and Normark, 1980). The scene was thus set for the dramatic geological event to follow.

\section{Diffuse Extension: 5.5 Ma-3.5 Ma}

At about 5.5 Ma (Fig. 5), transform motion between the Pacific and North American plates jumped inland to the northeast side of the present peninsula and the Pen- 


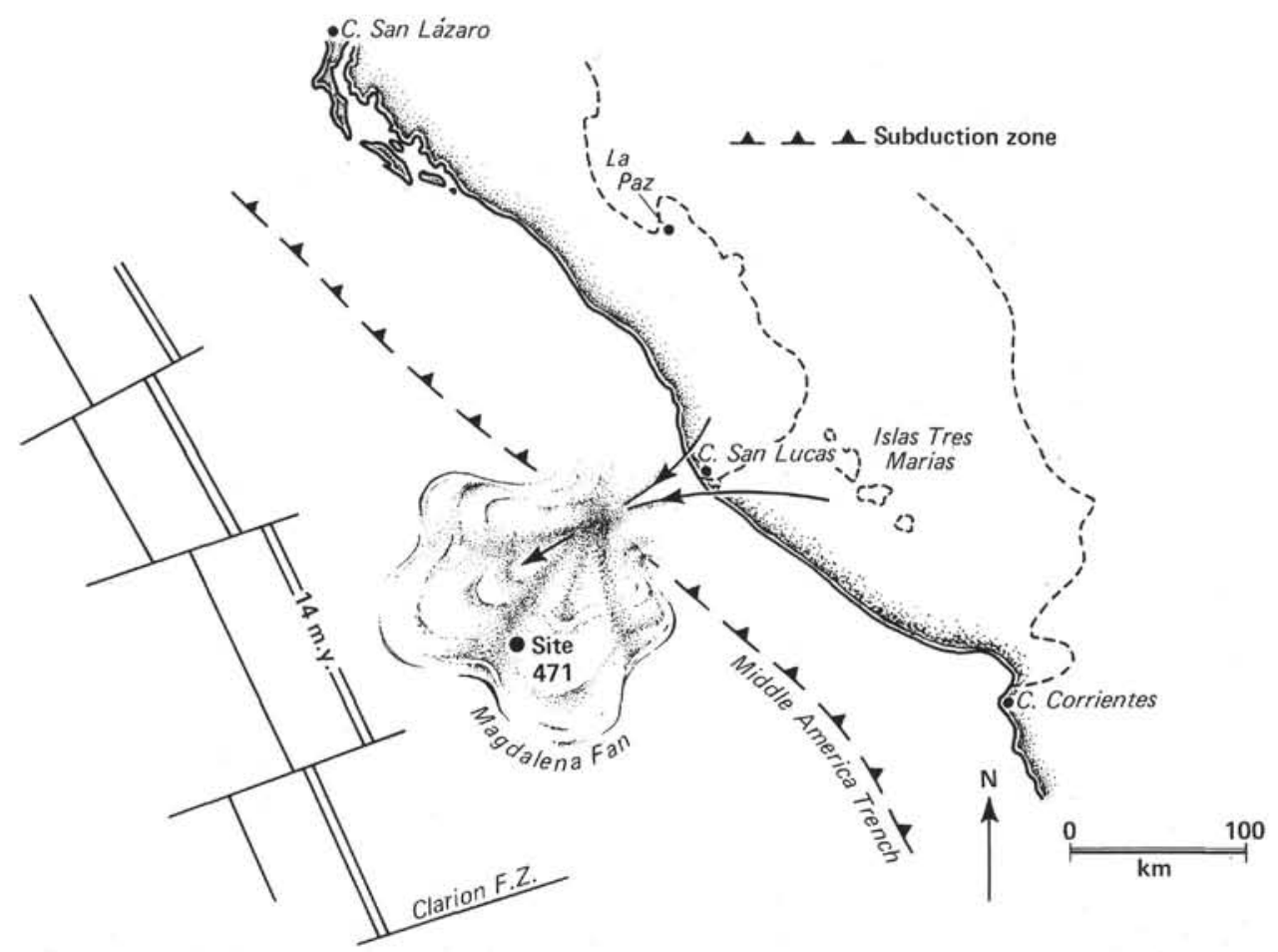

Figure 3. Restoration of the region around southern Baja California to its configuration of $\approx 14 \mathrm{Ma}$. The Gulf of California is closed (present shore lines of the Gulf are shown by dashed lines). The Pacific-Farallon spreading ridge (labeled 14 m.y.; Mammerickx and Klitgord, in press) lies well offshore and nearly parallel to the active subduction zone that is continuous along the entire coast. The Magdalena Fan lies outboard of the subduction zone west of present Cabo San Lucas and is receiving sediment from the granitic terrane to the east. DSDP Site 471 is shown.

insular Ranges Batholith of Baja California. Connected through a series of en echelon right-stepping offsets, it formed the nascent Gulf of California rifts and transforms and initiated the San Andreas Fault. Localization of the initial new transforms may have been controlled in part by the western edge of the earlier Basin and Range extensional faulting. Major right-slip motion of more than 24 m.y. duration on the plate edge thus stopped on the series of offshore transform faults off Baja and Southern California and on continental transform faults west of the new San Andreas in central California. Major reorganization of the geology of onshore Southern California began, and the initial phases of extensional rifting along offsets of the Gulf transforms began to separate a large segment of northwestern Mexico from the mainland.

During the 2 m.y. between 5.5 and 3.5 Ma (Fig. 6), a new ocean basin began to form, some of the major aspects of structure within the Gulf and on its continental margins were developed, and more than $112 \mathrm{~km}$ of northwesterly separation between the Peninsula and the conjugate mainland occurred. All of this took place without significant generation of new sea floor in the classic manner recorded by lineated magnetic anomalies.

In studies of the Gulf of Aden, Cochran (1981), as we have just noted, referred to this type of separation or rifting as diffuse extension; he also discussed sea-floor spreading in areas of high rates of deposition within the general context of magnetic quiet zones and diffuse extension. In the Gulf of California, we recognize four distinct types of diffuse extension that occurred before recognizable lineated anomalies developed. These types may grade one into the other but are not necessarily time-gradational, for all may be occurring simultaneously in a structural regime like that of the Gulf of California. They include

1) Block faulting and listric normal faulting with thinning of continental crust, accompanied by variable amounts of dike injection. No lineated magnetic anomalies are formed.

2) Mixing of thinned continental crustal fragments with newly generated ocean crust, with uncorrelatable magnetic anomalies.

3) Generation of new crust in an environment where deposition rates are high through injection of dikes and sills into soft young sediments, without lineated magnetic anomalies.

4) New oceanic crust generated with uncorrelated magnetic anomalies. Plate edges consist of many short spreading centers and transforms and these undergo frequent short-term rearrangement.

Block and listric normal faulting have been mapped southeast of the tip of the Peninsula, where the Gulf mouth transect of Sites 474-476 was drilled (see Curray et al., this volume, Pt. 2), and are probably also present on the conjugate margin of the Tres Marias block and the foundered continental fragments of the Maria Magdalena Rise (Figs. 7 and 8). This type of extension is also quite apparent from structure and topographic expression along the mainland Mexico margins in the southern 


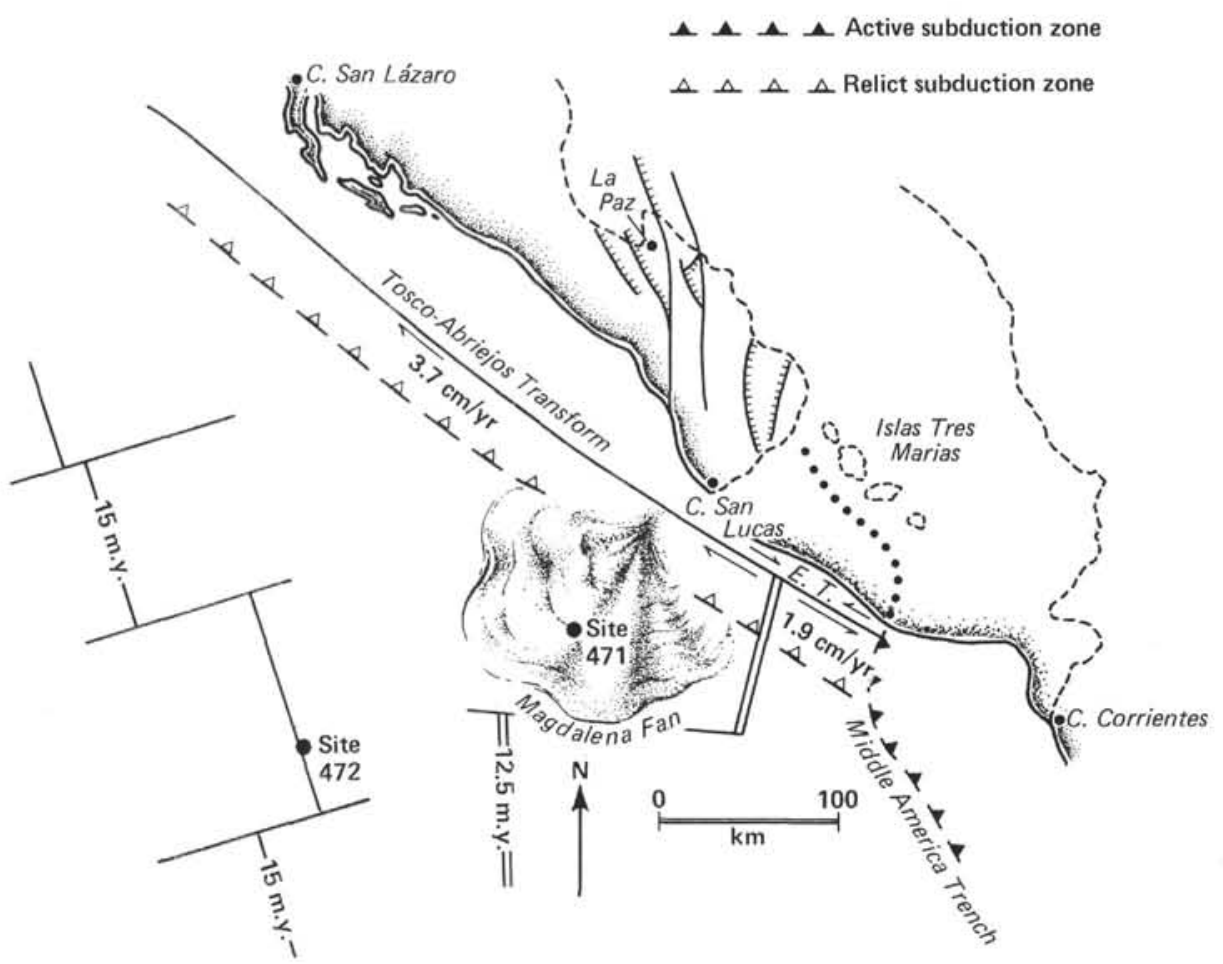

Figure 4. Region around southern Baja California restored to configuration of $12.5 \mathrm{Ma}$. The Gulf of California is closed (dashed lines show present coast, heavy dotted line shows present Tres Marias scarp). The Pacific-Farallon (Guadalupe) spreading ridge (double line, labeled $12.5 \mathrm{~m} . \mathrm{y}$.) has just jumped to a position south of present Cabo San Lucas (a transform-transform-ridge triple junction forms). The spreading has activated the Tosco-Abreojos transform fault to the north (with $3.7 \mathrm{~cm} / \mathrm{yr}$ right-slip motion) and the short Esplandian transform fault (labeled E.T., with $1.9 \mathrm{~cm} / \mathrm{yr}$ left-slip motion) that connects to the subduction zone to the southeast. Subduction along the Baja coast stops and a short new segment of subduction zone is added to the north end of the Middle America Trench. The 15 m.y. isochron is shown west of the active spreading center. DSDP Sites 471 and 472 are shown. The Magdalena Fan on the Pacific Plate begins to move to the northwest and is cut off from its source.

Gulf (Fig. 9A, B) and to a lesser extent off the Peninsula east of La Paz. It comprises a multitude of small blocks and axes of divergence that characterize a thinning and foundering continental margin. Ness and Lyle (in press) have recognized these blocky elements and define them also through gravimetric expression. Areas of mixed continental block and ocean crust are more difficult to define, but we suggest that at least parts of the Maria Magdalena Rise west of the northernmost of the Tres Marias group probably comprise this type of crust (Figs. 8 and 9A). Doubtless there are other local areas of this type to be mapped in the Gulf with more detailed surveys. The Maria Magdalena Rise is floored by crust with uncorrelatable magnetic anomalies although it is the area postulated by Mammerickx (1980) to be an old aborted spreading ridge. We suggest that the incoherent anomalies of the Rise developed as accretion of new crust took place through very short, nonaligned spreading segments between foundered continental blocks, resulting in a magnetic signature too chaotic to be defined with conventional surface-to-ship magnetic surveys. Through time, this type of continental-margin-sea-floor extension should normally evolve into pure sea-floor spreading, with generation of mappable lineated anomalies. Longer and more centralized spreading centers will form until finally a single, linear, axial ridge is developed, although the foundered blocks of altered continental crust will remain within the chaotic zone. In the history of the Gulf of California this event spanned a period of time from about $4.7 \mathrm{Ma}$ to $3.5 \mathrm{Ma}$, to begin the period of typical sea-floor spreading that has continued at the mouth of the Gulf to the present time. The diachronous nature of this event is discussed more fully by Curray et al. (this volume, Pt. 2).

Although the continental rifting that occurred during this early phase of opening of the Gulf is classed as diffuse extension, the major fracture zone boundaries of foundering blocks apparently were defined very early, or at the initiation of the process of extension. Figure 10 shows the reconstructed Gulf at $3.5 \mathrm{Ma}$, after 2 m.y. and $112 \mathrm{~km}$ of extension but before the Gulf mouth developed lineated anomalies connecting off the tip of the Peninsula from the Tamayo Fracture Zone to the Rivera Fracture Zone. It is significant that the major structurally and topographically defined fracture zones of the Gulf were well developed at this early stage. The fracture zones can, in fact, be traced essentially to the limits of earliest extension. Thus, although extension has occurred through foundering of multiple small blocks and bounding centers of extension, the major 

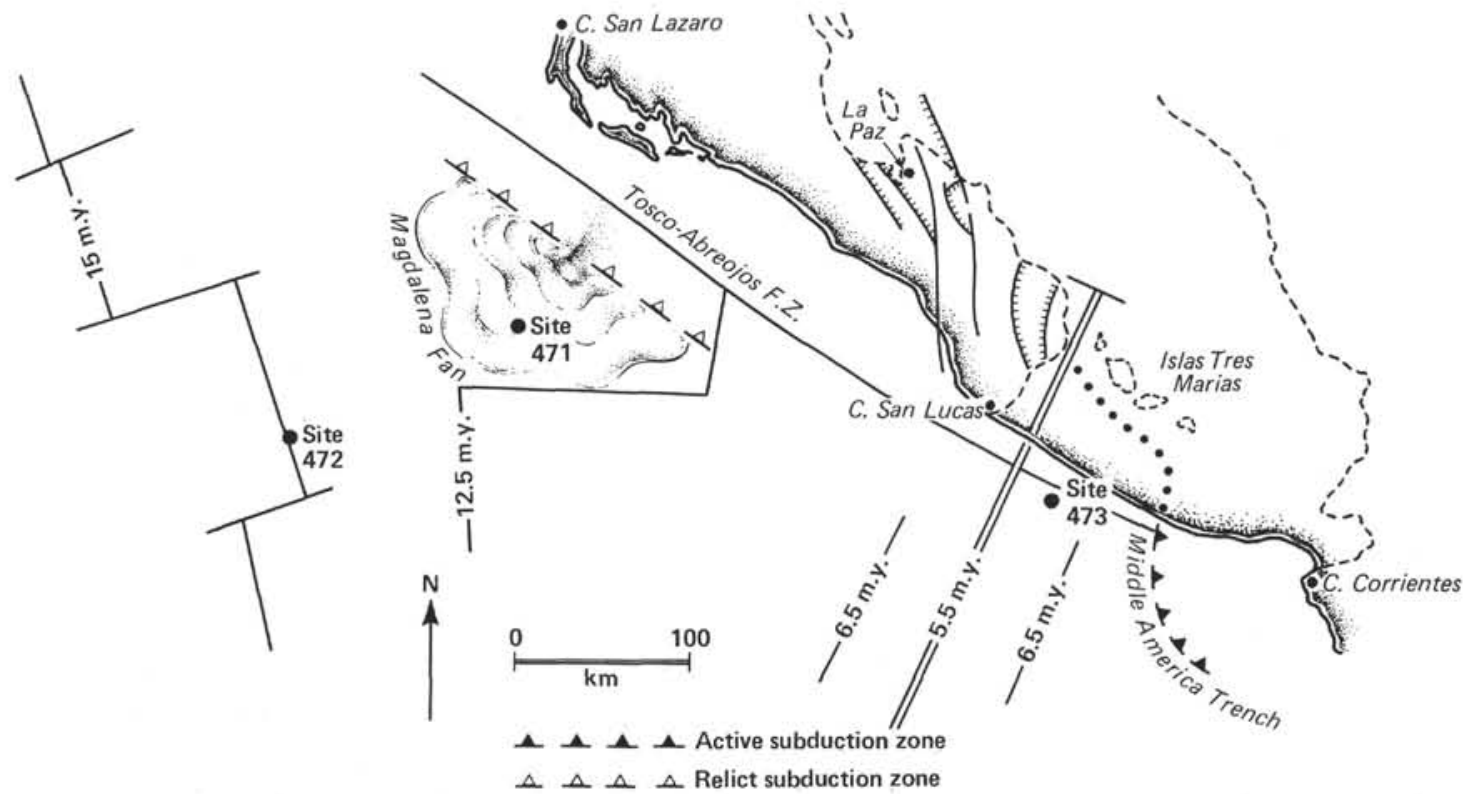

Figure 5. The region around southern Baja California is shown restored to its configuration of 5.5 Ma. (Dashed lines show present coast, heavy dotted line shows Tres Marias scarp.) The active spreading ridge (double line labeled 5.5 m.y.) has propagated to the east side of the southern Baja California Batholith to initiate right-slip continental transform fault motion. Rifting of Baja California away from the mainland begins. Motion on the offshore transform faults to the west stops after translating the Magdalena Fan $261 \mathrm{~km}$ northwest to its present position, where it was drilled on Leg 63, Site 471. The former subduction zone and buried trench also moved to the northwest on that side of the spreading ridge but do not exist southeast of the $12.5 \mathrm{~m} . \mathrm{y}$. isochron. On the southeast side of the spreading ridge the old trench and the trench slope terrane south of the transform have been subducted in the northern end of the Middle America subduction zone. Approximate positions of the $6.5,12.5$, and 15 m.y. isochrons are shown, as are Sites 471,472 , and 473 .
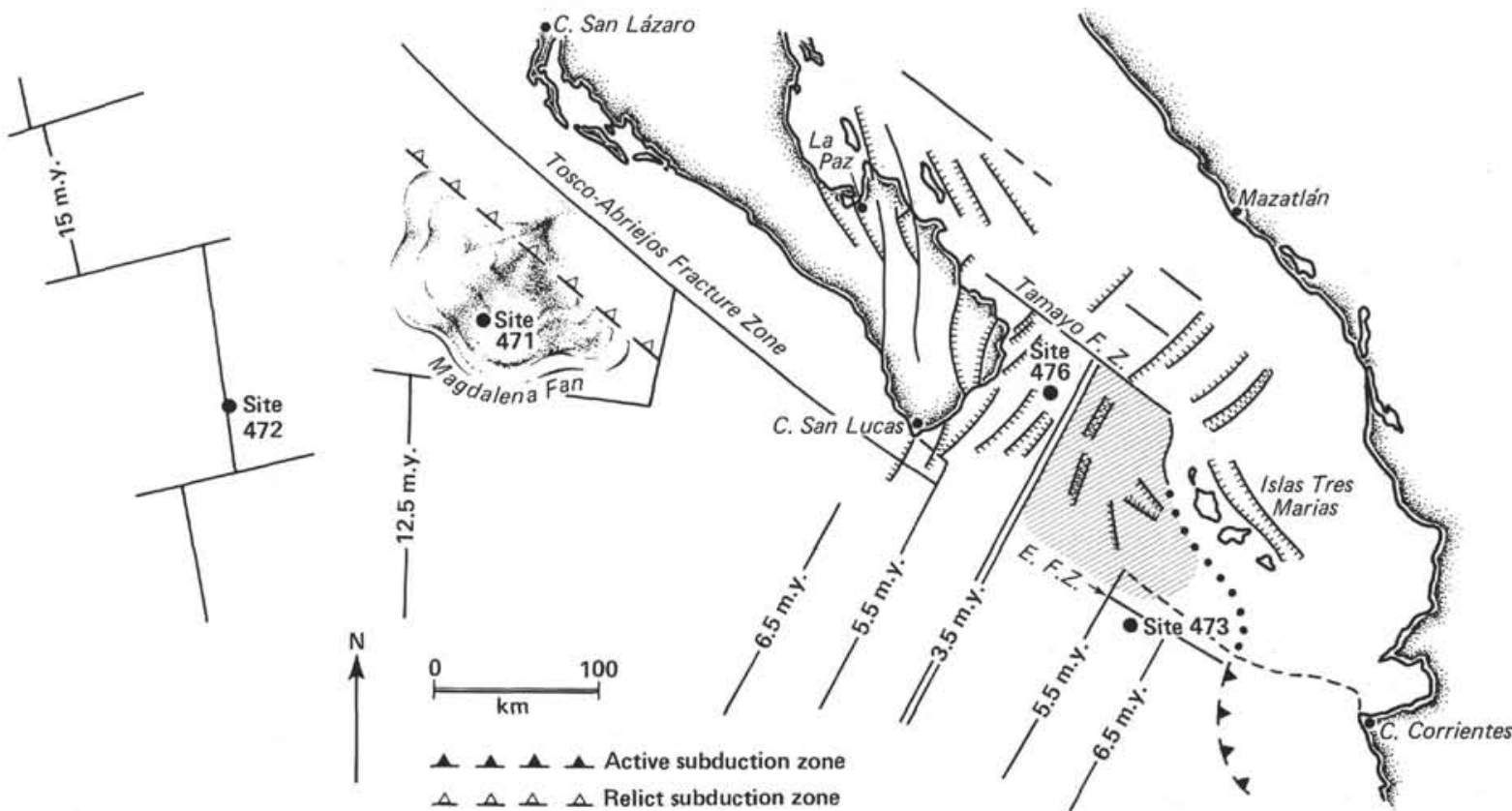

Figure 6. The region around southern Baja California reconstructed to its configuration of 3.5 Ma. Baja California has been rifted $112 \mathrm{~km}$ away from the conjugate margin of the Tres Marias continental block by rifting and spreading on the spreading center at the Gulf mouth. Spreading is by extensional faulting and crustal attenuation of the continental margins. The granitic margin off Baja California has subsided to 2659 meters at Site 476. On the southeast side of the spreading center the foundered margin of the Tres Marias continental block now forms the Maria Magdalena Rise (shaded area; old shoreline shown by dashed line; heavy dotted line shows Tres Marias scarp; see Fig. 8). Approximate isochrons are shown on the sea floor to the west. Within the Gulf, crustal attenuation by extensional block and listric normal faulting has developed numerous foundered fragments of continental margin blocks (see Fig. 9A, B). 


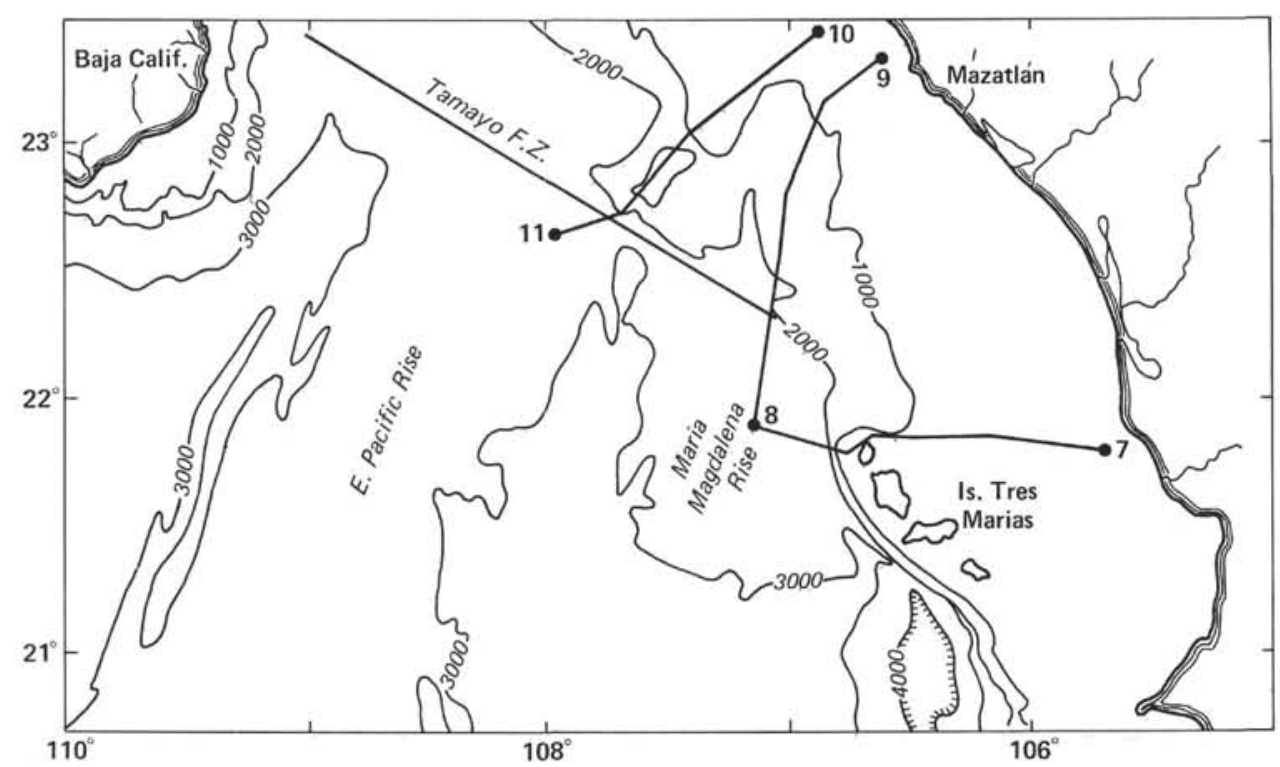

Figure 7. Locations of seismic profiling transects 7-8, 8-9, and 10-11 of Figures 8 and $9 \mathrm{~A}, \mathrm{~B}$, respectively.

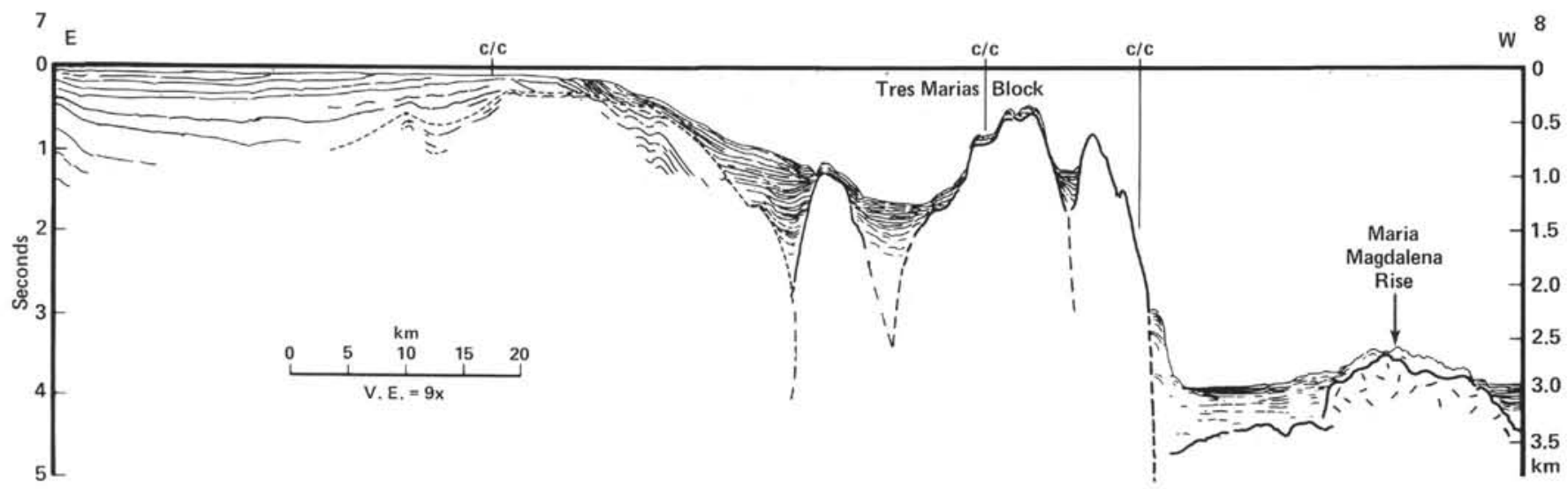

Figure 8. Line drawing of seismic profile across the foundered continental margin of the Tres Marias block and the probable continental fragment of the Maria Magdalena Rise (line drawing from Moore, 1973). See Figure 7 for location.

and controlling boundaries defined by the fracture zones apparently are much deeper-seated and were established essentially at the initiation of continental rifting.

\section{Initiation of Spreading Centers: 3.5 Ma-Present}

Before 3.5 Ma, diffuse extension of types 1 and 2 accounted for nearly all of the $112 \mathrm{~km}$ of opening that began 2 m.y. earlier. Small areas of lineated sea-floor spreading anomalies occur at the tip of the Peninsula flanking the zone of prominent block faulting (Curray et al., this volume, Pt. 2), but both at the Gulf mouth and to the north in the new Gulf, organized spreading centers had probably not developed to a significant extent. Starting at $3.5 \mathrm{Ma}$ (Figs. 6 and 10), spreading was localized along a single, continuous, spreading axis at the Gulf mouth extending from the Tamayo to the Rivera fracture zones, and thenceforth to the present it has generated the lineated sea-floor magnetic anomalies that are associated with sea-floor spreading in the open oceanic environment.
Probably at about this same time, within the Gulf, extension by crustal thinning through block and listric normal faulting with accompanying dike injection had nearly run its course and further diffuse extension was composed of types 3 and 4 . Type 3 , the formation of new crust by injection of sills and dikes into soft, unconsolidated, young sediments, can occur either in zones of small-scale plate-edge offsets or at well-defined spreading centers such as those drilled at Sites 477,478 , and 481 in the Guaymas Basin. In neither case, however, will magnetic anomalies typical of oceanic sea-floor spreading be developed, because significant amounts of basalts are not extruded onto the sea floor from linear sources. The Guaymas Basin drilling of Leg 64 was designed to study the processes and products of this type of formation of new crust; it is reported in other summary chapters (this volume, Sect. G, Pt. 2).

Generation of new oceanic crust by diffuse injection of magma at multiple, short, noncorrelatable sections (type 4) probably occurred east of the Tamayo Fracture 


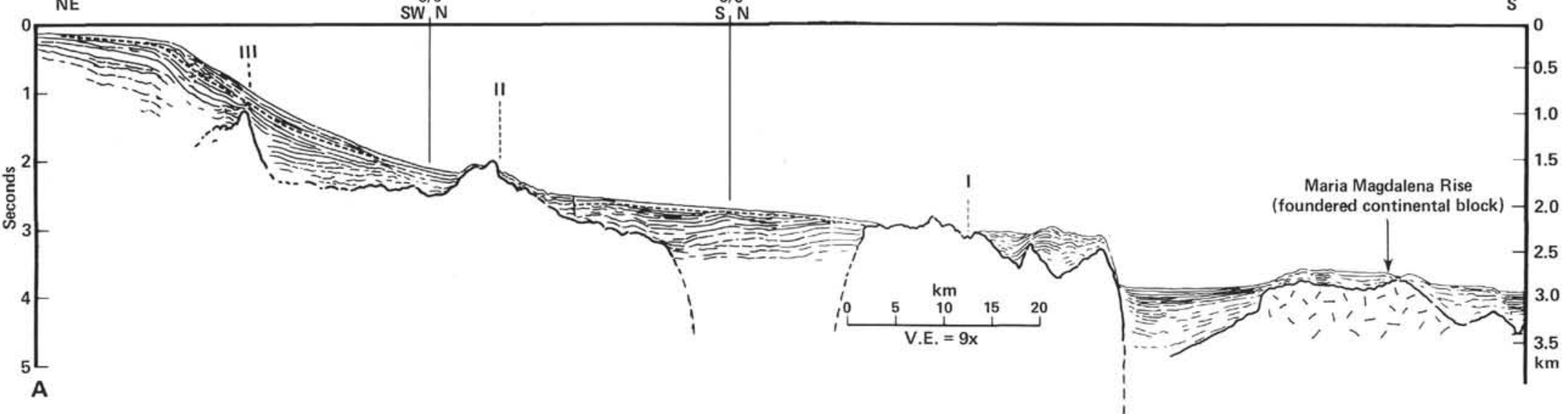

10

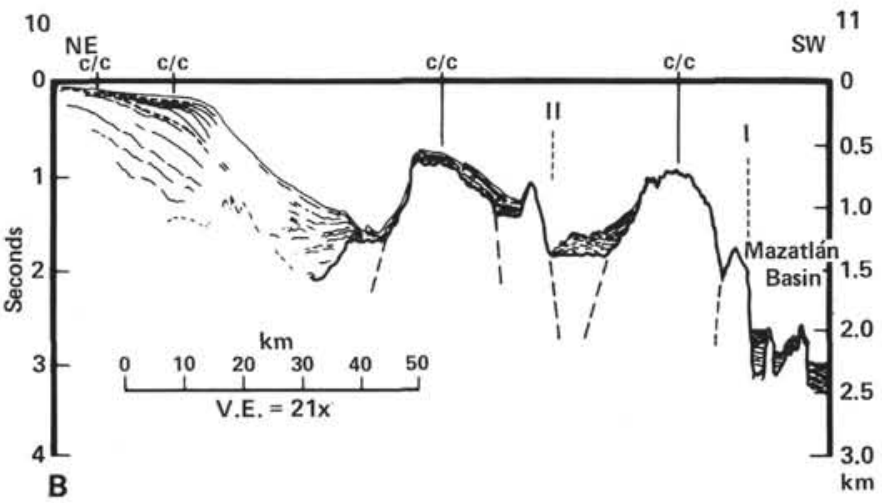

Figure 9. A. Line drawing of seismic profile across the attenuated and foundered continental crust east of the north end of Islas Tres Marias. Roman numerals I, II, and III are positions of fracture zones. I is the Tamayo Fracture Zone. Line drawing is from Moore (1973). B. Line drawing of seismic profile crossing foundered continental blocks off Mazatlan. Roman numerals I and II are fracture zones. I is Tamayo Fracture Zone. Line drawing is from Moore (1973). 


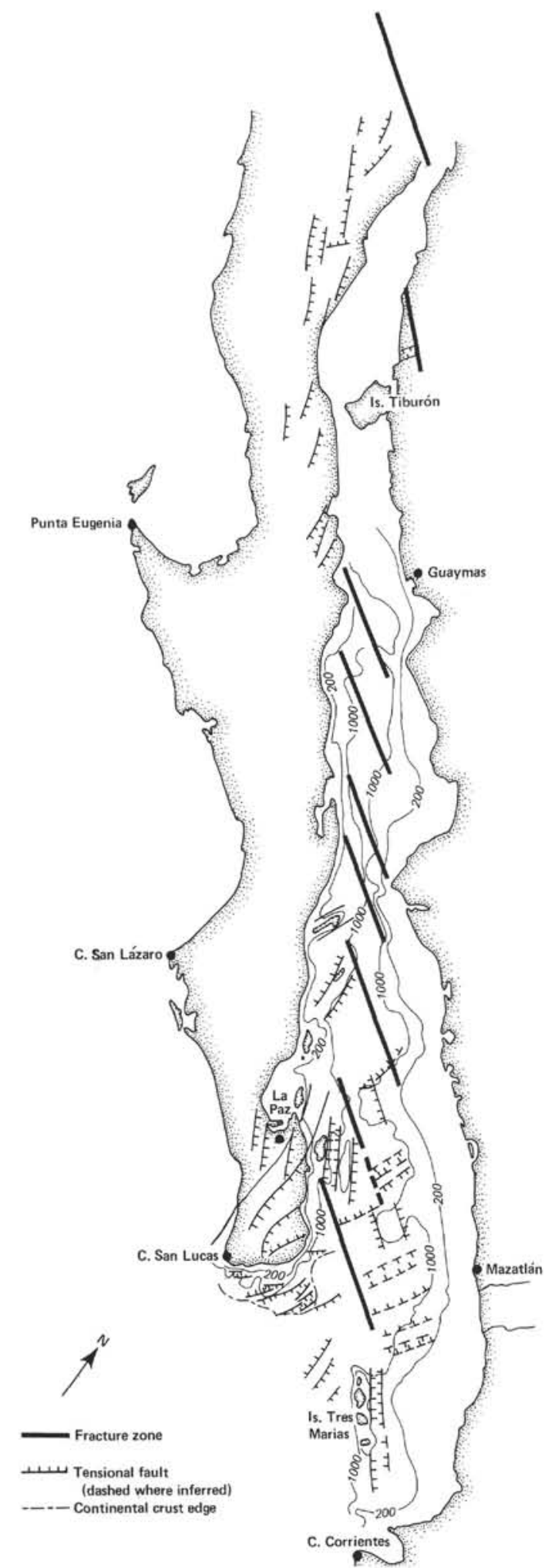

Figure 10. Reconstruction showing the Gulf of California at its configuration of $3.5 \mathrm{Ma}$, just prior to development of lineated magnetic anomalies from the Rivera Fracture Zone to the Tamayo Fracture Zone. The Peninsula has moved $112 \mathrm{~km}$ to the northwest during the preceding $2 \mathrm{~m}$.y. Spreading has been largely by extensional block and normal listric faulting attenuating continental crust. Many foundered blocks are defined in the southern Gulf by faults. Note that the major fracture zones are developed in this early phase of opening and are mapped by topography and seismic reflection (Moore, 1973). Onshore faults are from USGS Map I-512 (1966), and Gastil and Krunmenacker, 1977.
Zone prior to the development of lineated anomalies (Fig. 3). The process may still continue in the basin east of $\mathrm{La} \mathrm{Paz}$, where sedimentation rates are not so great as to the north.

\section{DISCUSSION}

The foregoing scenario for the tectonic and geologic evolution of the Gulf of California was developed to best satisfy constraints imposed by known bathymetric, geological, and geophysical data and to include the formation of the Gulf within the structural evolution of the larger region of western California and Mexico. As in all such hypotheses, however, there remain some problems that cannot be readily explained.

\section{Structure of the Northern Gulf versus the Southern Gulf}

Examination of Figures 1 and 10 reveals certain contrasts between the Gulf north of Isla Tiburón and that portion to the south. Whereas the northern Gulf is completely closed by the reconstruction of $300 \mathrm{~km}$ of motion along the azimuth of the average major transforms, the southern Gulf closes only to about the 1000- to 500-meter contours. Existing data within the northern Gulf, furthermore, show no obvious extensional block and listric normal faulting so prominent on the southern mainland continental margin. An explanation for these north-to-south differences in the Gulf is probably, in part, the prodigious influx of sediment into the northern Gulf from the Colorado River. In essence, the Salton Trough (the northernmost expression of the Gulf of California structural depression) and the northern Gulf of California have, from the initiation of rifting through the more mature generation of new crust, been kept brimful of sediment delivered by the Colorado River. The possible presence of any blocks of attenuated continental crust like those to the south may thus be hidden beneath the thick cover of detritus. The tightness of our reconstructed fit (Fig. 1), however, suggests that a more plausible explanation for the lack of collapse structure is that it has never developed. If the attenuation of continental crust is a function of down-to-basin collapse by gravity tectonics, then perhaps the pulled-apart continental edges are buttressed by the influx of Colorado River sediment; gravity-induced faulting has not occurred or is less developed than that to the south.

\section{Age of Oldest Sediment in the Gulf}

Our proposed history of the opening of the Gulf of California, starting $5.5 \mathrm{Ma}$, clearly implies that there should be no sediments older than $5.5 \mathrm{~m}$.y. deposited in the earliest Gulf. Various reports have, however, noted the presence of upper Miocene marine strata in the early "Gulf of California" from the Lake Mead area of southern Nevada (Blair, 1978), from southwestern Arizona (Eberly and Stanley, 1978), from the northern Gulf coast of Baja California (Ingle, 1973) and from the coast of Sonora (Gomez, 1971). Good paleontological and radiometric dates demonstrate that some of these strata are at least $8 \mathrm{~m}$.y. old. All of these sediments are deposited in block-faulted terranes developed during the late Miocene Basin and Range crustal attenuation. Other than shelf deposits, no sediments older than 5.5 
m.y. have been reported from the margins of the southern Gulf. In the deep waters of the Gulf, oldest sediments cored at Site 474 at the Gulf mouth on the foundered continental margin of the tip of Baja are 4.5 m.y. old. Sediments dredged from the base of the deepest fault-bounded exposures of the Guaymas Basin (Fig. 11; Moore, 1973) did not yield unequivocal ages from foraminifers and were barren of nannofossils. Diatoms, however, gave ages of 0.63 to $1.8 \mathrm{~m}$.y. (Schrader, pers. comm.). We suggest that the $8+\mathrm{m} . \mathrm{y}$. old marine sediments of southern Nevada and Arizona, Sonora, and northern Baja California may not be related to a protoGulf of California, but could instead be evidence of an inland sea resulting from crustal extension in the Basin and Range Province of those localities. We see no compelling reason to relate these deposits to a long, narrow seaway extending to the latitude of the present southern Gulf of California. They could plausibly be evidence of an inland sea whose entry to the Pacific was at the latitude of the present Los Angeles Basin.

An alternate hypothesis is that the La Paz Fault and associated north-south-trending tensional faults of the southern end of the Baja Peninsula are the southernmost representatives of the Basin and Range extensional faulting that was most active 6-9 Ma (Dokka and Merriam, 1979). An attractive aspect of this hypothesis is that east-west extension of about $75 \mathrm{~km}$, in the region east of and including part of the Peninsula south of $\mathrm{La}$ $\mathrm{Paz}$, could account for the offset in the trend of the batholith between the Peninsula and Islas Tres Marias and the mainland to the south. That amount of eastwest extension would also close the 1000 -meter isobath east of the southern peninsula in our Figure 1. If this hypothesis is valid, then there may indeed have been a shallow proto-Gulf created by largely east-west basin range extensional faulting 6-9 Ma, before plate-edge transform motion began about 5.5 Ma. This kind of a proto-Gulf would not, however, have participated in the northwesterly translation of Baja California away from its conjugate margin on the mainland to the south. Acceptance of this hypothesis also implies that there are marine sediments older than 5.5 m.y. in the southern Gulf. If these older sediments do indeed exist, they would be relatively thin, shallow-water deposits associated with the more deeply subsided crustal blocks of the

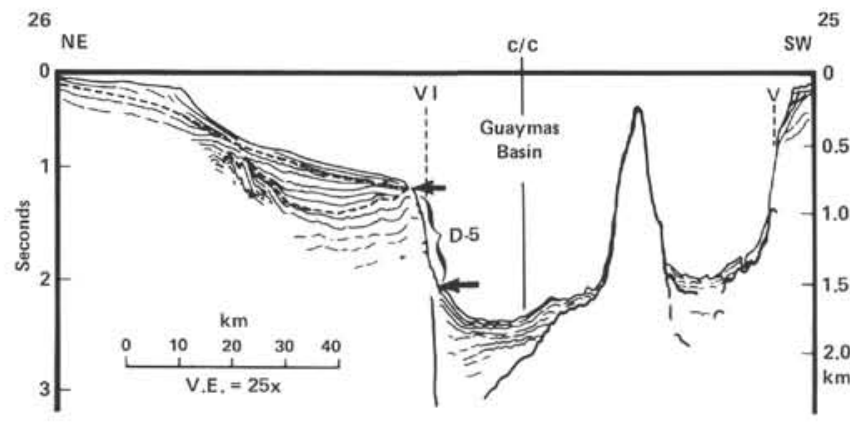

Figure 11. Line drawing of seismic profile across Guaymas Basin showing scarp formed by transform fault (labeled VI) and position of dredge site D-5 of Moore (1973). Diatoms from dredged sediments gave ages of only 0.63 to $1.8 \mathrm{~m}$.y. (Schrader, pers. comm.). foundered continental margins of the oceanic Gulf of California.

\section{Implications for Faulting Chronology in Central and Southern California}

Our model for the opening of the Gulf of California requires that virtually all of the Pacific-North American plate motion during the past $5.5 \mathrm{~m} . \mathrm{y}$. has been taken up within the Gulf transform fault-spreading center system and along the San Andreas Fault per se and its direct branches. This requirement is in conflict with the concept that the entire region of Southern California and the Basin and Range Province is a wide transform boundary (Atwater, 1970) within which diffuse shear results and major right-slip faulting may occur at any time. Dickinson and Snyder (1979) have contrasted the concept of a broad zone of oblique crustal extension as a result of lateral drag along the transform fault with other hypotheses explaining the tensional tectonics of the region. They invoke the concept of "slab window tectonics" as an alternative hypothesis which more adequately fits the timing of structural events. The concept involves cutoff of subduction with the southward passage of the triple junction down the coast, formation of a region free of a descending slab of cold oceanic crust, and consequent upwelling of hot asthenosphere from below the area of the former slab. The upwelling impinges on the base of the North American Plate and accounts for the extensional east-west tectonics of the Basin and Range region, in a time sequence that Dickinson and Snyder believe is compatible with development of a slabfree region. Our model for the opening of the Gulf of California supports this type of structural evolution, in which transform motion of the structural regime of the past $5.5 \mathrm{~m} . \mathrm{y}$. is essentially superimposed on the older, extensional tectonics.

The worldwide data set used by Minster and Jordan (1978) to develop an instantaneous-motion model did not utilize data along the San Andreas Fault because of the complication in the Basin and Range Province. Their model does, however, predict a $5.6 \mathrm{~cm} / \mathrm{yr}$ relative motion between the Pacific and North American plates in central California. This rate is essentially the same as that measured by magnetic anomalies at the mouth of the Gulf (Lewis et al., 1975; Ness et al., 1981) and is utilized in our model for the opening of the Gulf. Minster and Jordan (1978) discuss the possibility that a significant fraction of the motion across the plates in central California could be taken up on faults other than the modern San Andreas. Our model argues against this concept and implies that rates lower than $5.6 \mathrm{~cm} / \mathrm{yr}$, determined by geodetical (Thatcher, 1977) or short-period geological (Hall and Sieh, 1977) methods, do not cover a sufficient time period to make it possible to define long-term rates adequately. If this is correct, the low strain rates measured, or implied, by the short-term methods suggest that very large amounts of stress have accumulated that are yet to be released by major earthquakes on the transform plate boundary.

Seismicity on faults flanking the major plate-edge transform and its direct branches (Friedman et al., 1976; Fuis et al., 1977) also requires an explanation if 
our hypothesis is valid. We suggest that much of this type of seismicity is related to flexure of the plate margins imposed by bends or other irregularities in the principal, active, plate-to-plate transform fault surface. The "big bend" in the San Andreas at the Transverse Ranges is the outstanding example of a structure generating this type of marginal intraplate strain, but many smaller irregularities may impose similar stresses. Release of these stresses can be manifested as normal, right, or left components of slip (all are known; see Legg, 1979). The motion would normally take place on older reactivated fault surfaces and would be of small magnitude.

Another possible explanation for the recent seismic activity off plate boundaries in Baja and Southern California is that it is a relatively recent geological phenomenon that has not been active long enough to be detectable in the long-term geological record of offset terranes.

\section{Summary and Conclusions}

We propose that the Baja California Peninsula is restored to its former position adjacent to mainland Mexico by $300 \mathrm{~km}$ of motion along the azimuth of the major Gulf fracture zones. This is the amount of offset required by Gastil and his colleagues for retrofitting geological phenomena across the Gulf and it is also the amount required by Matthews, Ehlig, and others for restoring offset along the San Andreas Fault in central and Southern California. Our proposed scenario for the opening of the Gulf to this current $300-\mathrm{km}$ limit does not require separate earlier formation of a proto-Gulf of California, with attendant northwesterly movement of the Peninsula, but instead postulates opening by a single two-phased process. The first phase, which is still occurring in the central and northern Gulf, was diffuse extension following a jump of the plate edge from transform motion off the west coast to approximately the back or northeast side of the coastal batholith. Diffuse extension includes rifting and dilation of continental crust, accompanied by dike injection, as well as formation of oceanic crust without lineated magnetic anomalies being generated. The present pattern of fracture zones and transform faults appears to have been established during this early phase of diffuse extension. Assuming a constant displacement of $5.6 \mathrm{~cm} / \mathrm{yr}$ between the North American and the Pacific plates, first opening began about $5.5 \mathrm{Ma}$ and the change to the second phase of opening with the formation of lineated magnetic anomalies at the mouth of the Gulf was completed by about 3.5 Ma. Also at about 3.5 Ma extension by continental attenuation had nearly ended and the generation of new crust began within the Gulf at both diffuse and discrete spreading centers through the injection of basalt into soft sediments. This model implies essentially monolithic separation of the Baja California Peninsula from the mainland; it does not require a spreading axis jump at the mouth $3.5 \mathrm{Ma}$; and it specifically rejects northwestward subduction beneath the tip of the Peninsula.
We believe that the tighter fit of the northern as compared to the southern Gulf in this restoration may result from lack of, or lesser amounts of, tensional down-tobasin gravity faulting. Such faulting, in the Gulf north of Isla Tiburón, has perhaps been precluded by the very high depositional rates that continuously maintain the structural basins there nearly brimful.

Our proposed history of the Gulf, starting 5.5 Ma, clearly implies that no marine basin sediments predating that time should exist in the Gulf. Reports of marine sediments at least 8 m.y. old in the northern Gulf margins in southwestern Arizona and the Lake Mead area of southern Nevada have related these sediments to the earliest Gulf of California. We suggest that these are not structurally related to the Gulf, but to a shallow inland sea formed by basin and range crustal extension at that earlier time.

Our scenario for the opening of the Gulf requires that virtually all of the right-slip interplate motion of the past $5.5 \mathrm{~m}$.y. has been taken up on the San Andreas Fault per se and its direct branches. Seismicity on other faults in the regions is either related to flexing of near plate edge areas that is caused by irregularities along the primary slip surfaces or results from tectonic activity too young to be recorded in the long-term geological record of offset terranes.

\section{REFERENCES}

Anderson, J. G., 1979. Estimating the seismicity from geologic structure for seismic risk studies. Seismol. Soc. Am. Bull., 55:753-797.

Atwater, T., 1970. Implications of plate tectonics for the Cenozoic tectonic evolution of western North America. Bull. Geol. Soc. Am., 81:3513-3536.

Atwater, T., and Molnar, P., 1973. Relative motion of the Pacific and North American Plates deduced from sea floor spreading in the Atlantic, Indian and South Pacific Oceans. In Kovack, R. L., and Nur, A. (Eds.), Proceedings of the Conference on Tectonic Problems of the San Andreas Fault System. Stanford Univ. Publ. Geol. Sci., 13:136-148.

Batiza, R., and Chase, C. G., 1981. Magnetic evidence for a Miocene fossil spreading center south of Isla Guadalupe, E. Pacific near $29^{\circ} \mathrm{N}$, Nature, 289:787-789.

Blair, W. N., 1978. Gulf of California in Lake Mead area of Arizona and Nevada during late Miocene time. Bull. Am. Assoc. Pet. Geol., 62:1159-1170.

Blake, M. C., Jr., Campbell, R. H., Dibblee, T. W., Howell, D. G., Nilsen, T. H., Normark, W. R., Vedder, J. C., and Silver, E. A., 1978. Neogene basin formation in relation to plate-tectonic evolution of San Andreas Fault system, California. Bull. Am. Assoc. Pet. Geol., 62:344-372.

Chase, C. G., Menard, H. W., Larson, R. L., et al., 1970. History of sea floor spreading west of Baja California. Bull. Geol. Soc. Am., 81:491-498.

Cochran, J. R., 1981. The Gulf of Aden: Structure and evolution of a young ocean basin and continental margin. J. Geophys. Res., 86: 263-287.

Coperude, S. P., 1978. Geologic structure of the western continental margin of south central Baja California based on seismic and potential field data [M.S. thesis]. Oregon State University.

Crouch, J. K., 1979. Neogene tectonic evolution of the California Continental Borderland and western Transverse Ranges. Bull. Geol. Soc. Am., 90:338-345.

Dickinson, W. R., and Snyder, W. S., 1979. Geometry of subducted slabs related to San Andreas transform. J. Geol., 87:609-627.

Dokka, R. K., and Merriam, R. H., 1979. Tectonic evolution of the main gulf escarpment between latitude $31^{\circ} \mathrm{N}$ and $30^{\circ} \mathrm{N}$, northeastern Baja California, Mexico. In Abbott, P. L., and Gastil, R. G. 
(Eds.), Baja California Geology: Field Guides and Papers: San Diego (Dept. of Geol. Sci., San Diego State Univ.), pp. 139-148.

Eberly, L. D., and Stanley, T. B., Jr., 1978. Cenozoic stratigraphy and geologic history of southwestern Arizona. Bull. Geol. Soc. Am., 89:921-940.

Ehlig, P. L., 1981. Origin and tectonic history of the basement terrane of the San Gabriel Mountains, central Transverse Ranges. In Ernst, W. G. (Ed.), The Geotectonic Development of California: New Jersey (Prentice-Hall, Inc.), pp. 254-283.

Friedman, M. E., Whitcomb, J. H., Allen, C. R., and Hileman, J. A., 1976. Seismicity of the Southern California Region I January 1972 to 31 December 1974. Calif. Inst. Technol. Div. Geol. Planet. Sci. Contribution 2734

Fuis, G. S., Friedman, M. E., and Hileman, J. A., 1977. Preliminary catalog of earthquakes in Southern California, July 1974-September 1976. U.S. Geol. Surv. Open File Rept. 77-181.

Gastil, G., and Krummenacker, D., 1977. Reconnaissance geology of coastal Sonora between Puerto Lobos and Bahía Kino. Bull. Geol. Soc. Am., 88:189-198.

Gastil, G., Krummenacker, D., and Minch, J., 1979. The record of Cenozoic vulcanism around the Gulf of California. Bull. Geol. Soc. Am., 90:839-857.

Gastil, G., Morgan, G., and Krummenacker, D., 1981. The tectonic history of peninsular California and adjacent Mexico. In Ernst, W. G. (Ed.), The Geotectonic Development of California: New Jersey (Prentice-Hall, Inc.), pp. 285-306.

Gomez, J., 1971. Sobre la presencia de estratos marinos del Mioceno en el Estado de Sonora, Mexico. Rev. Inst. Mex. Pet., 3:77-78.

Hall, N. T., and Sieh, K. E., 1977. Late Holocene rate of slip on the San Andreas Fault in the northern Carrizo Plain, San Luis Obispo County, California. Geol. Soc. Am. Abstract with Programs, 9:428. (Abstract)

Huehn, B., 1977. Crustal structure of the Baja peninsula between latitudes $22^{\circ} \mathrm{N}$ and $25^{\circ} \mathrm{N}$ [M.S. thesis]. Oregon State University.

Ingle, J. C., 1973. Neogene marine history of the Gulf of California. Geol. Soc. Am. Abstracts with Programs, 5:62. (Abstract)

Klitgord, K. D., and Mammerickx, J., in press. East Pacific Rise, magnetic anomaly and bathymetric framework. J. Geophys. Res.

Larson, R. L., 1972. Bathymetry, magnetic anomalies, and plate tectonic history of the mouth of the Gulf of California. Bull. Geol. Soc. Am., 83:3345-3360.

Larson, R. L., Menard, H. W., and Smith, S. M., 1968. Gulf of California: A result of ocean floor spreading and transform faulting. Science, 73:3361-3397.

Legg, M. R., 1979. Faulting and earthquakes in the inner borderland offshore Southern California and northern Baja California [M.S. thesis]. University of California, San Diego-Scripps Institution of Oceanography.

Lewis, B. T. R., McClain, J., Snydsman, W. E., Lister, C. R. B., Holmes, M. L., and Heitman, C., 1975. Gulf of California IPOD site survey, final report. Unpublished manuscript.
McKenzie, D. P., and Morgan, W. J., 1969. Evolution of triple junctions. Nature, 224:125-133.

Mammerickx, J., 1980. Neogene reorganization of spreading between the Tamayo and Rivera Fracture Zones. Mar. Geophys. Res., 4: 305-318.

Mammerickx, J., and Klitgord, K. D., in press. East Pacific Rise: Evolution from 25 mybp to the present. J. Geophys. Res.

Matthews, V., 1976. Correlation of Pinnacles and Neenach volcanic formations and their bearing on San Andreas fault problem. Bull. Am. Assoc. Pet. Geol., 60:2128-2141.

Menard, H. W., 1978. Fragmentation of the Farallon plate by pivoting subduction. J. Geol., 86:99-110.

Minch, J. A., 1972. The late Mesozoic-early Tertiary framework of continental sedimentation, northern Peninsular Ranges, Baja California, Mexico [Ph.D. dissert.]. University of California, Riverside.

Minster, J. B., and Jordan, T. H., 1978. Present-day plate motions. J. Geophys. Res., 83:5331-5354.

Moore, D. G., 1973. Plate-edge deformation and crustal growth, Gulf of California structural province. Bull. Geol. Soc. Am., 84:18831906.

Moore, D. G., and Buffington, E. C., 1968. Transform faulting and growth of the Gulf of California since late Pliocene. Science, 161: $1238-1241$.

Ness, G. E., and Lyle, M. W., in press. A history of continental rifting at the mouth of the Gulf of California. Proceedings of Planetary Rifting Conf., 2-4 Dec. 1981.

Ness, G. E., Sanchez, Z. O., Couch, R. W., and Yeats, R. S., 1981. Bathymetry and oceanic crustal ages in the vicinity of the mouth of the Gulf of California, illustrated using Deep Sea Drilling Project Leg 63 underway geophysical profiles. In Yeats, R. S., Haq, B. U. et al., Init. Repts. DSDP, 63: Washington (U.S. Govt. Printing Office), 919-923.

Spencer, J. E., and Normark, W. R., 1979. Tosco-Abreojos fault zone: A Neogene transform plate boundary within the Pacific margin of southern Baja California, Mexico. Geology, 7:554-557.

Suppe, J., 1970. Offset of the late Mesozoic basement terrains by the San Andreas fault system. Bull. Geol. Soc. Am., 81:3253-3257.

Thatcher, W., 1977. Secular deformation, episodic movements, and relative plate motions in Southern California. Trans. AGU (Eos), 58:496. (Abstract)

U.S. Geological Survey, 1966. Geologic Map of California. U.S. Geol. Surv. Misc. Geol. Inv. Map I-512.

Wilson, J. T., 1965. A new class of faults and their bearing on continental drift. Nature, 207:343-347.

Yeats, R. S., and Haq, B. U., 1981. Deep sea drilling off the Californias: Implications of Leg 63. In Yeats, R. S., Haq, B. U., et al., Init. Repts. DSDP, 63: Washington (U.S. Govt. Printing Office), 949-962.

Yeats, R. S., Haq, B. U., et al., 1981. Init. Repts. DSDP, 63: Washington (U.S. Govt. Printing Office). 